\title{
ASOSIASI LITERASI KESEHATAN DAN HEALTH BELIEF MODEL DENGAN PRAKTIK SADARI PADA MAHASISWI UNIVERSITAS INDONESIA
}

\author{
Dian Priharja Putri ${ }^{1)}$, Dien Anshari ${ }^{2)}$ \\ Fakultas Kesehatan Masayrakat Universitas Indonesia \\ dian.priharja@ui.ac.id
}

\begin{abstract}
ABSTRAK
Kanker payudara menempati urutan pertama dengan jumlah kasus baru (43,3\%) dan kematian akibat kanker (12,9\%) pada wanita di dunia [1]. Lebih dari 70\% pasien datang ke layanan kesehatan pada stadium kenker yang telah lanjut [2]. Pemeriksaan Payudara Sendiri (SADARI) yang dilakukan setiap bulan merupakan metode deteksi dini termurah dan paling sederhana yang dapat dilakukan secara mandiri oleh wanita. Meskipun telah direkomendasikan selama bertahun-tahun, praktik BSE masih rendah. Lebih dari $80 \%$ orang tidak memahami praktik SADARI [3]. Program ini tidak dapat dipisahkan dari literasi kesehatan. Teori Health Belief Model dianggap dianggap sesuai untuk melihat mengapa bebrapa orang memilih untuk tidak melakukan SADARI. Penelitian ini untuk melihat asosiasi literasi kesehatan dan Health Belief Model dengan praktik SADARI, menggunakan desain cross-sectional dengan sampel 251 mahasiswa S1 Reguler dari Universitas Indonesia angkatan 2018/2019. Hasil yang diperoleh mahasiswi memiliki tingkat pengetahuan yang rendah $(51,4 \%)$ dan memiliki literasi kesehatan yang rendah $(49,0 \%)$. Literasi kesehatan mempunyai hubungan yang bermakna dengan praktik SADARI $(\mathrm{p}=0,000 ; \alpha=0,05)$ setelah dikontrol oleh rumpun ilmu, sumber informasi, dan pengetahuan. Persepsi terhadap kemampuan diri melakukan SADARI mempunyai hubungan bermakna dengan praktik $\mathrm{SADARI}(\mathrm{p}=$ $0,000 ; \alpha=0,05)$ setelah dikontrol oleh rumpun ilmu, sumber informasi, dan pengetahuan.
\end{abstract}

Kata Kunci- Breast Cancer, BSE, Health Literacy, Health Belief Model

\section{PENDAHULUAN}

Kanker payudara masih menempati urutan pertama dengan jumlah kasus baru tertinggi $(43,3 \%)$ dan kematian akibat kanker (12,9\%) yang menyerang wanita di dunia [1]. Menurut Badan Penyelenggara Jaminan Sosial bahwa kanker payudara $(43,3 \%)$, kanker prostat $(30,7 \%)$, dan kanker paru-paru $(23,1 \%)$ adalah jenis kanker dengan persentase kasus baru tertinggi dan merupakan penyebab kasus kematian tertinggi akibat kanker di Indonesia [4]. Masalah kanker payudara lebih besar karena lebih dari 70\% pasien datang ke layanan kesehatan pada stadium lanjut [2]. 80\% kasus kanker ditemukan pada stadium lanjut. Kondisi ini mempersulit proses penanganan penyakit dan dapat menyebabkan tingkat kematian yang tinggi. Oleh karena itu perlu dilakukan upaya pencegahan, diagnosis dini, pengobatan kuratif, dan paliatif, serta upaya rehabilitasi yang baik, sehingga pelayanan kepada pasien dapat dilakukan secara optimal [5]. Studi empiris menunjukkan bahwa Pemeriksaan Payudara Sendiri (SADARI), pemeriksaan payudara klinis, dan mamografi dapat menjadi alat untuk deteksi dini untuk menentukan apakah ada kelainan, kerusakan, atau gangguan pada payudara [6]. Lebih dari 95\% kanker payudara pada stadium awal dan 65\% kanker payudara pada stadium lanjut dapat dideteksi oleh wanita saja [7]. Meskipun telah direkomendasikan selama bertahun-tahun, praktik rutin SADARI di banyak negara masih rendah. Di Indonesia, 51,9\% siswa melakukan SADARI, tetapi hanya 3,3\% yang melakukannya secara teratur [8]. Faktanya ditemukan bahwa $80 \%$ masyarakat tidak memahami praktek SADARI [3]. Keberhasilan program manajemen penyakit kronis (termasuk kanker) tidak dapat dipisahkan dari kemampuan individu dalam mengakses, memahami, dan menggunakan informasi dan layanan kesehatan untuk membuat keputusan perawatan kesehatan yang dikenal sebagai litersi kesehatan [9]. Tingkat literasi kesehatan yang rendah akan meningkatkan jumlah penyakit kronis hingga $47 \%$ dari total beban penyakit [10]. Meningkatkan literasi 
kesehatan individu tidak hanya menghasilkan kesehatan yang lebih baik, tetapi juga mengurangi biaya perawatan kesehatan [11]. Kanker menempati urutan kedua dengan jumlah biaya perawatan kesehatan tertinggi dari 2014 hingga 2016 dengan total biaya perawatan kesehatan 6,6 triliun dari total 37 triliun total biaya layanan kesehatan. Pada Agustus 2018, pengeluaran BPJS Kesehatan untuk membiayai penyakit-penyakit katastropik mencapai 12 triliun atau sekitar 20,07\% dari total biaya layanan kesehatan. Ini dianggap sebagai salah satu penyebab defisit Dana Jaminan Sosial yang dikelola oleh BPJS Kesehatan [12].

Kemampuan seseorang untuk mengambil keputusan dipengaruhi oleh persepsi mereka. Persepsi melalui pendekatan Health Belief Model dan literasi kesehatan secara bersama-sama efektif dalam mendorong adopsi perilaku pencegahan merokok di kalangan siswa [13]. Persepsi tentang praktik SADARI dapat dilihat dalam konteks Health Belief Model [14]. Model ini menjelaskan partisipasi individu dalam program praktik pencegahan penyakit dan promosi kesehatan [7]. Dalam Health Belief Model, wanita yang menganggap diri mereka rentan terhadap kanker payudara dan percaya bahwa kanker payudara adalah penyakit serius, lebih cenderung melakukan SADARI. Selain itu, wanita cenderung melakukan SADARI jika mempunyai hambatan yang rendah untuk melakukan SADARI, percaya pada manfaat SADARI, memiliki motivasi hidup sehat dan keyakinan kesehatan, dan mempunyai kemampuan untuk melakukan SADARI.

Berdasarkan data dan fakta yang disajikan di atas, praktik SADARI sangat penting sebagai langkah awal dalam deteksi dini kanker payudara pada wanita. Penelitian terkait asosiasi literasi kesehatan dan Health Belief Model dengan deteksi dini kanker payudara masih sangat minim. Mahasiswa Universitas Indonesia diharapkan menjadi agen perubahan yang memiliki pengetahuan dan praktik yang baik pada deteksi dini kanker payudara, terutama SADARI di lingkungan sekitarnya.

\section{METODE}

Penelitian ini menggunakan desain kuantitatif dengan metode cross sectional. Populasi adalah 3.177 mahasiswa S1 Reguler dari 2018/2019 dari 14 Fakultas. Penelitian dilakukan pada Bulan Juli 2019 Metode pengambilan sampel yang digunakan adalah non-probability sampling dengan purposive sampling. Sampel penelitian sebesar 251 siswa yang dibagi menjadi tiga rumpun ilmu (Sains dan Teknologi, Sosial dan Humaniora, dan Rumpun Ilmu Kesehatan).. Penelitian ini menggunakan data primer dengan alat pengumpulan data berupa kuesioner daring. Menggunakan Champion's HBM Scale (CHBMS) untuk menilai persepsi dan HLS-EU-Q16 untuk menilai literasi kesehatan. Analisis data berupa analisis univariat untuk melihat distribusi frekuensi dan menggambarkan variabel sehingga karakteristik dan variasi variabel dapat diidentifikasi, analisis bivariat untuk melihat hubungan antara variabel independen yang tergantung menggunakan uji Chi-square dan regresi logistik, dan analisis multivariat untuk meminimalkan bias menggunakan uji statistik regresi logistik. Data disajikan dalam bentuk tabel.

\section{HASIL \& PEMBAHASAN}

Hasil uji normalitas dalam penelitian ini yang menunjukkan nilai kurang dari sama dengan dua pada hasil bagi skewness dengan standar error adalah variabel pengetahuan, literasi kesehatan, dan persepsi terhadap kemampuan diri kemampuan diri melakukan SADARI. Disimpulkan bahwa varibel tersebut memiliki data yang terdistribusi normal. Oleh karena itu, nilai batas atau cut off point yang digunakan dalam pengkategorian setiap 
variable yang berdistribusi normal adalah nilai rata-rata/mean. Untuk varibel persepsi terhadap keseriusan, persepsi terhadap kerentanan, persepsi terhadap manfaat, dan persepsi terhadap hambatan tidak berdisitribusi normal, untuk itu nilai batas atau cut off point yang digunakan adalah nilai tengah/median.

Responden dalam penelitian ini terdiri dari tiga rumpun ilmu, yaitu Rumpun Sains dan Teknologi (72 responden), Rumpun Ilmu Sosial dan Humaniora (119 responden), dan Rumpun Ilmu Kesehatan (60 responden). Mahasiswa S1 reguler di Universitas Indonesia angkatan 2018/2019 yang mempraktikkan SADARI sebanyak 156 siswa (62,2\%). Sumber informasi yang paling banyak diperoleh responden berasal dari internet, yaitu sebesar $47,4 \%$ dan poster $23,5 \%$. Sedangkan booklet adalah jenis sumber informasi yang paling sedikit diperoleh oleh mahasisiwi $(2,4 \%)$. Pengetahuan rata-rata mahasiswi S1reguler Universitas Indonesia angkatan 2018/2019 terkait dengan kanker payudara dan praktik BSE adalah 66,41 dengan rentang nilai 0-100 dan 51,4\% mahasiswi memiliki pengetahuan rendah tentang kanker payudara dan SADARI.

Rata-rata persepsi keseriusan kanker payudara pada mahasiswi S1 reguler Universitas Indonesia angkatan 2018/2019 adalah 66,63 dengan rentang nilai 0-100 dan 160 responden (63,7\%) memiliki persepsi serius terhadap kanker payudara. Rata-rata persepsi terhadap kerentanan kanker payudara pada mahasiswi S1 reguler Universitas Indonesia angkatan 2018/2019 adalah 48,00 dengan rentang nilai 0-100 dan diketahui 62,9\% mahasiswi memiliki persepsi rentan terhadap kanker payudara. Rata- rata persepsi terhadap manfaat melakukan SADARI pada mahsasisiwi S1 reguler Universitas Indonesia angkatan 2018/2019 adalah 80,00 dengan rentang nilai 0-100 dan 64,5\% mahasiswi memiliki persepsi bahwa SADARI memiliki manfaat tinggi. Rata-rata persepsi terhadap hambatan untuk melakukan SADARI pada mahsasisiwi S1 reguler Universitas Indonesia angkatan 2018/2019 adalah 80,00 dengan rentang nilai 0-100 dan 66,5\% mahasisiwi memiliki hambatan rendah dalam melakukan BSE. Rata-rata persepsi kemampuan untuk melakukan SADARI pada mahasiswa S1 Reguler Universitas Indonesia angkatan 2018/2019 adalah 51,37 dengan rentang nilai 0-100 dan 195 mahasiswi (77,7\%) mampu melakukan SADARI. Rata-rata literasi kesehatan pada mahasiswi S1 reguler Universitas Indonesia angkatan 2018/2019 adalah 79,63 dengan rentang nilai 0-100 dan 49,0\% dari mahasiswi memiliki tingkat literasi kesehatan yang rendah. Berdasarkan domain literasi kesehatan, rata-rata domain fungsional adalah 82,20 (95\% CI: 80,77-83,27) dengan rentang nilai 0- 100, sedangkan yang terendah adalah domain literasi kesehatan kritis dengan nilai rata-rata 75,73 (95\% CI :74,14-76,92). Variabel literasi kesehatan memiliki hubungan yang bermakna dengan persepsi kemampuan diri melakukan SADARI, di mana nilai p <0,05 dengan nilai OR 3,2. Ini berarti bahwa mahasisiwi yang memiliki literasi kesehatan yang tinggi memiliki kemampuan diri melakukan SADARI 3 kali lebih besar dibandingkan dengan mahasisiswi yang memiliki literasi kesehatan yang rendah. 
Tabel 1

Model Akhir Multivariat yang Berhubungan dengan Praktik SADARI

\begin{tabular}{lccc}
\hline \multicolumn{1}{c}{ Variabel } & P-value & OR & CI 95\% \\
\hline $\begin{array}{l}\text { Literasi kesehatan } \\
\text { Literasi kesehatan }\end{array}$ & 0,0001 & 16,872 & $5,452-52,211$ \\
\hline Rumpun Ilmu (1) & 0,158 & 2,141 & $0,744-6,166$ \\
\hline Rumpun Ilmu (2) & 0,926 & 1,054 & $0,351-3,165$ \\
\hline Sumber informasi & 0,887 & 29,545 & $11,787-74,056$ \\
\hline Pengetahuan & 0,0001 & 0,942 & $0,415-2,139$ \\
\hline Persepsi terhadap manfaat & & & $0,253-3,263$ \\
\hline Persepsi manfaat & 0,883 & 2,909 & $0,298-4,020$ \\
\hline Rumpun Ilmu (1) & 0,893 & 1,094 & $0,179-1,398$ \\
\hline Rumpun Ilmu (2) & 0,187 & 0,501 & $21,859-61,661$ \\
\hline Sumber informasi & 0,0001 & 20,714 & $3,695-25,563$ \\
\hline Persepsi terhadap kemampuan diri & & & $0,397-2,748$ \\
\hline Persepsi kemampuan diri & 0,0001 & 9,719 & $0,117-1,051$ \\
\hline Rumpun Ilmu (1) & 0,930 & 1,044 & $19,883-49583$ \\
\hline Rumpun Ilmu (2) & 0,061 & 0,350 & $0,383-1,898$ \\
\hline Sumber informasi & 0,0001 & 29,770 & \\
\hline Pengetahuan & 0,696 & 0,852 & \\
\hline
\end{tabular}

Berdasarka tabel 1, rumpun ilmu, sumber informasi, dan pengetahuan merupakan confounding hubungan literasi kesehatan dan praktik SADARI. Dengan nilai OR 16,872, dapat disimpulkan bahwa mahasiswi yang mempunyai literasi kesehatan tinggi mempunyai peluang 17 kali melakukan praktik SADARI dibandingkan dengan mahasiswi yang mempunyai literasi kesehatan rendah setelah dikontrol dengan variabel rumpun ilmu, sumber infromasi, dan pengetahuan. Sedangkan rumpun ilmu, sumber informasi, dan pengetahuan merupakan confounding hubungan persepsi terhadap kemampuan diri melakukan SADARI dan praktik SADARI. Dengan nilai OR 9,719, dapat disimpulkan bahwa mahasiswi yang mempunyai persepsi mampu untuk melakukan SADARI peluang 9 kali melakukan praktik SADARI dibandingkan dengan mahasiswi yang mempunyaipersepsi kurang mampu untuk melakukan SADARI setelah dikontrol dengan variabel rumpun ilmu, sumber infromasi, dan pengetahuan.

Pada penelitian ini tidak ditemukan adanya variabel yang berinteraksi. Pada uji confounding ditemukan variabel confounding yaitu variabel rumpun ilmu, sumber informasi, dan pengetahuan yang dapat diartikan variabel tersebut mempengaruhi hubungan literasi kesehatan dengan praktik SADARI. Pada analisis multivariat penelitian menunjukkan bahwa, setelah hubungan literasi kesehatan dengan praktik SADARI dikontrol oleh variabel rumpun ilmu, sumber informasi, dan pengetahuan didapatkan hasil p-value 0,0001 dengan nilai OR sebesar 16,872 (95\% CI 5,452-52,211). Sehingga dalam penelitian ini hipotesis diterima yaitu ada hubungan antara literasi kesehatan dengan praktik SADARI.

Literasi kesehatan merupakan komponen penting komunikasi kesehatan. WHO meneyebutkan bahwa literasi kesehatan sebagai faktor penting dalam promosi kesehatan (WHO, 2010). United State Agency for International Development (USAID) tahun 2012 mengemukakan bahwa literasi kesehatan sebagai penyumbang penting menuju masyarakat yang lebih sehat. Literasi kesehatan dapat meningkatkan kualitas pelayanan, hak dan tanggung jawab pasien, akses informasi dan pelayanan kesehatan. Oleh karena itu semakin tinggi literasi kesehatan terbukti peningkatan outcome kesehatan juga makin besar (IOM, 2003). Masyarakat dengan literasi kesehatan yang tidak memadai menghadapi banyak kendala ketika mengakses dan menggunakan sistem 
perawatan kesehatan. Disamping perlu upaya untuk meningkatkan akses masyarakat terhadap informasi kesehatan, juga diperlukan meningkatkan kemampuan mereka untuk menggunakan atau memanfaatkan informasi yag diperolehnya secara efektif (Nutbeam dalam Berry, 2007)

Pada penelitian ini tidak ditemukan adanya variabel yang berinteraksi. Pada uji confounding ditemukan variabel confounding yaitu variabel rumpun ilmu, sumber informasi, dan pengetahuan yang dapat diartikan variabel tersebut mempengaruhi hubungan persepsi terhadapkemampuan diri dengan praktik SADARI. Pada analisis multivariat penelitian menunjukkan bahwa, setelah hubungan persepsi terhadap kemampuan diri dengan praktik SADARI dikontrol oleh variabel rumpun ilmu, sumber informasi, dan pengetahuan didapatkan hasil p-value 0,0001 dengan nilai OR sebesar 9,719 (95\% CI 3,695-25,563). Sehingga dalam penelitian ini hipotesis diterima yaitu ada hubungan yang bermakna antara persepsi terhadap kemampuan diri dengan praktik SADARI.

Menurut Bandura (dalam Ragin 2011), keyakinan yang kuat terhadap kemampuan untuk melakukan suatu perilaku akan meningkatkan kemungkinan seseorang untuk melakukan perilaku tersebut. Efikasi juga terkait dengan potensi individu untuk berperilaku hidup sehat, yaitu orang yang tidak yakin bahwa mereka dapat melakukan suatu perilaku yang dapat menunjang kesehatan akan cenderung tidak ingin mencobanya (Bandura 1998, dalam Howard dan Schustack, 2008). Penelitian yang dilakukan oleh Anggai tahu 2015 ditemukan bahwa ada hubungan negatif yang sangat signifikan antara kemampuan diri dengan perilaku berisiko terhadap kesehatan pada remaja. Semakin tinggi kemampuan diri maka semakin rendah perilaku berisiko terhadap kesehatan, sebaliknya semakin rendah kemampuan diri maka semakin tinggi perilaku berisiko terhadap kesehatan. Peranan kemampuan diri atas perilaku berisiko terhadap kesehatan pada remaja sebesar 9,1\%. Hasil penelitian merupakan bukti ilmiah bahwa salah satu cara untuk mencegah munculnya perilaku berisiko terhadap kesehatan pada remaja adalah dengan meningkatkan efikasi diri.

\section{KESIMPULAN DAN REKOMENDASI}

Berdasarkan hasil penelitian dan pembahasan, dapat disimpulkan bahwa responden berasal dari tiga rumpun ilmu yaitu Saintek (72 responden), Soshum (119 responden), dan RIK (60 responden), 156 mahasiswi (62,2\%) yang melakukan SADARI, 66,9\% mahasiswi pernah mendapakan informasi terkait SADARI, mempunyai pengetahuan yang rendah $(51,4 \%)$, mempunyai persepsi keseriusan $(63,7 \%)$ dan peresepsi kerentanan $(62,9 \%)$, mempunyai persepsi manfaat tinggi (64,5\%) dan hambatan rendah (66,5\%), mampu melakukan SADARI (77,7\%), dan literasi kesehatan rendah (49,0\%). Praktik SADARI banyak dilakukan oleh mahasiswi RIK (68,5\%), informasi terkait SADARI banyak didapatkan oleh RIK (85,0\%), RIK mempunyai tingkat pengetahuan tinggi $(60,0 \%)$, persepsi keseriusan kanker payudara tinggi pada RIK $(88,83 \%)$ dan kerentanan tinggi pada rumpun Saintek (68,1\%), 100\% mahasiswa RIK dan Saintek mempunyai persepsi manfaat tinggi, hambatan melakukan SADARI banyak ditemukan pada rumpun Soshum (46,2\%), 57,78\% mahasiswa RIK mampu melakukan SADARI, dan lietrasi kesehatan tinggi pada RIK (65,0\%). Kemampuan diri melakukan SADARI mempunyai hubungan yang bermakna dengan literasi kesehatan. ( $\mathrm{p}=0,001, \mathrm{OR}=3,208,95 \% \mathrm{CI} 1,597$ 6,445). Mahasiswi yang mempunyai literasi kesehatan tinggi mempunyai peluang 17 kali melakukan praktik SADARI dibandingkan dengan mahasiswi yang mempunyai literasi kesehatan rendah setelah dikontrol dengan variabel rumpun ilmu, sumber infromasi, dan pengetahuan ( $\mathrm{p}=0,0001,95 \%$ CI 5,452-52,211). Dan mahasiswi yang mempunyai persepsi mampu untuk melakukan SADARI peluang 9 kali melakukan praktik SADARI 
dibandingkan dengan mahasiswi yang mempunyaipersepsi kurang mampu untuk melakukan SADARI setelah dikontrol dengan variabel rumpun ilmu, sumber infromasi, dan pengetahuan ( $\mathrm{p}=0,0001, \mathrm{OR}=3,695-25,563)$. Rekomendasi peneliti kepada Klinik Satelit UI dan unit K3L untuk membuat program intervensi guna meningkatkan angka partisipasi mahasiswi dalam melakukan SADARI dan membuat program intervensi untuk meningkatkan literasi kesehatan mahasiswa UI. Media promosi yang dibuat perlu memperhatikan sasarannya, seperti Rumpun Ilmu Sosial dan Humnaiora yang membutuhkan informasi yang lebih masif. Oleh karena itu penggunaan istilah kesehatan perlu dibuat sesederhana mungkin agar mudah dipahami.

\section{UCAPAN TERIMA KASIH}

Penulis mengucapka terima kasih kepada Universitas Indonesia yang telah memberikan ijin guna terselenggaranya penelitian ini dan memberikan data pendukung yang dibutuhkan dalam penelitian dan penulis mengucapakan terima kasih kepada Dien Anshari, S.Sos., M.Si., Ph.D yang telah memberikan masukan dan ilmu untuk kesempurnaan penelitian ini.

\section{REFERENSI}

1. Globocan. 2012. Estimated Disability (DALY) Worldwide Worldwide Dancers, Deaths, Prevalence, and Year of Life in 2008. IARC Cancer Base No. 11.

2. Saryono and Roischa D.P. (2009). Breast Care. Yogyakarta: Mitra Cendikia Press ..

3. Breast Cancer Foundation Jakarta. (2010). Adolescent Cancer Strikes Youth, (line), From: http://www.ykpj.or.id/ [April 1, 2019].

4. Health Social Security Organizing Agency. (2017). Productivity and Efficiency of Hospital Management in the JKN and MEA Era at the Persi National Seminar and Palembang Hospital.

5. Health Social Security Organizing Agency. (2017). Productivity and Efficiency of Hospital Management in the JKN and MEA Era at the Persi National Seminar and Palembang Hospital.

6. Sharma, R.A., Harris, A.L., Dalgleish, A.G., Steward, W.P., \& O'Byrne., 2009, Angiogenesis as a biomarker and target in cancer chemoprevention, Lancet Oncol, 2, 726-732

7. Champion VL (1993). Enhancement Instrument for Breast Cancer Screening Behavior. Res Nurse 42 (3): $139-143$

8. Marsytah, Siti. 2013. An overview of BSE practice in Regular Undergraduate students at the University of Indonesia uses the Health Belief Model (HBM) approach. Depok: Universtas Indonesia.

9. Berkman, N. D., Davis, T. C., \& McCormack, L. (2010). Health Literacy: What is it? Health Communication Journal, 15 (SUPPL.2), 9-19. https://doi.org/10.1080/10810730.2010.499985.

10. Kanj, M., \& Mitic, W.,. 2009. Health Literacy and Health Promotion: Definitions, Concepts and Examples in the Eastern Mediterranean Region, At the 7th Global Conference on Health Promotion Promoting Health and Development: Closing the Implementation Gap (pp. 26- 30).

11. Kowalski, Kent C. (2009). Physical Activity Questionnaire for Older Children (PAQ-C) and Adolescents (PAQ-A) Manual. Health Journal,

12. Canada 12 (1): $1-5$

13. Health Research and Development Agency of the Ministry of Health of the Republic of Indonesia. 
(2018). Basic Health Research 2018. Jakarta: Ministry of Health of the Republic of Indonesia.

14. Panahi, R., Ramezankhani, A., Tavousi, M., \& Niknami, S. 2017. Adding Helath Literacy to the Health Belief Model: Effectiveness of Educational Interventions on Smoking Preventive Behavior among Students. Iran: In Press.

15. Rosenstock, I. M., 1966, Why do people use health services. Milbank Memorial Fund Quarterly, 83 (4), $1-32$.

16. World Health Organization, 2013, Health Literacy The Solid Facts, DK-2100 Copenhagen Ø, Denmark.

17. Institute of Medicine.2010. Dietary Reference Intake for Energy, Carbohydrates, Fibers, Fats, Fatty Acids, Cholesterol, Proteins and Amino Acids. Panel Report on Macronutrients, Subcommittee on Reference Levels on Nutrition and Interpretation and Use of Diet Reference Intakes, and Standing Committee for Scientific Evaluation of Diet Reference Intakes. Press National Academy, Washington, DC.

18. Berry, Dianne. (2017). Theory and Practice of Health Communication. Open University Press, Education Mc Graw Hill: England.

19. Rahma, A. N. (2011). Relationship between Self-Efficacy and Social Support with Adolescent Adaptation at the Orphanage. Journal of Islamic Psychology, Vol. 8 No. 2, pp. 231-246

20. Ragin, D. F. (2011). Health Psychology An Interdisciplinary Approach to Health. Boston: Pearson

21. Anggani, D.M. (2010). Relationship Between Self Regulated Learning and Academic Achievement. Thesis. Now. Catholic University of Soegijapranata. 